\title{
Prospects for the use of Caragana fruits (Caragana arborescens and $C$. frutex) as alternative raw materials for the food industry
}

\author{
Ekaterina Solomonova ${ }^{1}$, Nikolay Trusov ${ }^{2 *}$, Tatiana Nozdrina $^{3}$ and Nikolay Kuvshinchikov ${ }^{3}$ \\ ${ }^{1}$ Russian State Agrarian University - Moscow Timiryazev Agricultural Academy, 127550 Moscow, \\ Russia \\ ${ }^{2}$ Tsytsin Main Botanical Garden of Russian Academy of Science, 127276 Moscow, Russia \\ ${ }^{3}$ Moscow State University of Food Production, 125080 Moscow, Russia
}

\begin{abstract}
Currently, there is an increase in the world's population against the background of a reduction in land suitable for growing traditional agricultural crops. This is especially true for Asian countries. Due to a number of factors, the areas of fertile land are decreasing, and the areas of saline land are increasing; arid areas of the planet are expanding. In this regard, it is important to introduce plants into the culture that can grow on poor, arid, saline soils. The purpose of the research is to study vegetable raw materials from fruits Caragana arborescens and C. frutex, undergoing introduction tests in the arboretum of the Tsytsin Main Botanical Garden of Russian Academy of Sciences, to find out the possibilities and advantages of their use in the food industry in a comparative aspect. A comparative assessment of the size and weight characteristics of the fruits and seeds of $C$. arborescens and $C$. frutex studied by us indicates the possibilities of their industrial food use in the future, along with a good introduction, and, probably, plantation potential of these plants.
\end{abstract}

\section{Intoduction}

Currently, there is an increase in the world's population against the background of a reduction in land suitable for growing traditional agricultural crops. This is especially true for Asian countries. Due to a number of factors, the areas of fertile land are decreasing, and the areas of saline land are increasing; the arid areas of the planet are expanding.

Introduction of new types of alternative plant raw materials into the culture can be associated with an increase in the range of nutrients (vitamins and other valuable substances) in the human diet [1-3], as well as with the possibility of growing new alternative plants in unsuitable conditions for the growth of major food crops.

Genus Caragana Fabr. of Fabaceae Lindl. family, of Faboideae Rudd subfamily includes, according to various data, from 40 to 100 species. On the territory of Russia, more than 10 species of Caragana grow in natural conditions [4-6]. Caragans are frost-resistant, drought-resistant shrubs capable of growing on poor soils, including alkali soils [4].

\footnotetext{
* Corresponding author: n-trusov@mail.ru
} 
Since the beginning of the last century, caragana tree $-C$. arborescens Lam. and caragana shrub - C. frutex (L.) K.Koch have been actively used in garden and park construction in Russia and abroad. Their mature fruits have become the objects of our research, because plants that have long been used in gardening have proven themselves well, thanks to their unpretentiousness, fast growth rate, and early (from 2-5 years) abundant annual flowering and fruiting $[4,5]$.

On the other hand, the high nutritional value of beans traditionally cultivated representatives of the family - peas, beans, soybeans, lentils, etc. - is well known. Despite the intense bitter taste of Caragana fruits and seeds, they are used for making side dishes, soups, seasonings and even a substitute for coffee [7-9]. Young beans are eaten cooked [8, $10,11]$. C. arborescens seeds contain up to $12.4 \%$ fatty oil and up to $36 \%$ protein [11] and recommended for use in extreme conditions [12]. At the same time, it is believed that $C$. arborescens can become one of the new plantation crops in areas with a continental climate [13]. This is primarily due to the possibility of growing it on poor, even highly alkaline soils, as well as its rapid growth, drought and frost resistance [14-17].

Representatives of the Fabaceae family are characterized by a variety of fruits (beans) according to the method of opening, size and number of seeds, external shape, crosssectional shape, etc. Typical for legumes, Caragana fruits are monomeric single-nest beans; the leathery pericarp of the mature fruit is brownish-brown, the surface is uneven; cylindrical seeds of black, brown or olive color are attached to the seam on the ventral side, on each leaf being located in one row [18].

Fruits, as a rule, accumulate the most significant substances necessary for the development of the embryo of the daughter sporophyte. Data on the qualitative composition of the vegetative structures of Caragana indicate the probable nutritional and, possibly, pharmacological value of their fruits. The presence of flavonoids (apigenin, quercetin, kaempferol, luteolin, luteolin-7-glycoside, rutin), phenol-carboxylic acids, polysaccharides, tannins, coumarins and 18 amino acids, 7 of which are essential, has been found in the shoots of caragana tree. Caragana extracts have hepatoprotective, hypoglycemic, antiinflammatory and wound healing effects $[19,20]$.

It was found that the storage containers of spare products in mature Caragana seeds are endosperm cells containing protein, fatty oil and mucus consisting of galactomannans, as well as cells of the storage parenchyma of cotyledons of the embryo, filled with protein, fatty oil and a large amount of starch [18].

The aim of the study is a comparative assessment of the potential of food use of $C$. arborescens and $C$. frutex fruits growing in the Moscow region.

To achieve this goal, the fruits and their parts (pericarp and seeds) of $C$. arborescens and $C$. frutex were studied in a comparative aspect:

- analysis of the morphological structure of mature fruits;

- determination of morphometric parameters of fruits and seeds;

- determination of the total number of seeds, as well as the number and fractions of mature and underdeveloped seeds in the fruit;

- determination of the mass and mass fraction of fruits and their parts;

- determination of the content of absolutely dry matter in the air-dry parts of fruits;

- statistical processing of the obtained data: calculation of arithmetic mean values, confidence intervals, coefficients of variation and accuracy indicators of experiments; comparison of parameters of two species corresponding to each other according to the Student's criterion.

\section{Materials and methods}


In the areas of natural habitats, $C$. arborescens and $C$. frutex are distributed mainly in forest and forest-steppe zones.

C. arborescens is a tall deciduous shrub or a small tree, height is 4-6 m; the root system is rod-shaped, with a large number of adventitious roots; it doesn't form root growth and stem axes of renewal; crown diameter is up to 5 meters; stems are thin, flexible, elastic, appressed-pubescent; leaves are compound pinnate, length is up to $10 \mathrm{~cm}$, with 4-7 (8) pairs of leaflets; flowers are of pea-like type, yellow, collected in bundles of 2-5 pcs., rarely solitary. It blooms in late May-June for about two weeks; bears fruits in July-August. Fruits are beans, linear-cylindrical, slightly curved at the end or straight, length is $3.5-6.5 \mathrm{~cm}, 3.5$ $5.0 \mathrm{~mm}$ in diameter, cracking at both seams. The fruit contains 5-8 oblong light yellow, olive-tinged seeds, about $4.5 \mathrm{~mm}$ in length and $3.3 \mathrm{~mm}$ in thickness. Mass of a thousand seeds is $25-44 \mathrm{~g}$ [4]. The fruits ripen at the end of July. C. arborescens blooms and bears fruit from 2 years of age [5].

For $C$. arborescens, it is shown that the size of fruits and seeds, and the number of seeds in the fruit are different for different geographical locations and in different light conditions. The length of the fruit is $2.5-5.9 \mathrm{~cm}$, width is $0.1-0.8 \mathrm{~cm}$. The number of seeds in the fruit is $1-8$ pcs. The length of the seed is 4,5-6,0 $\mathrm{mm}$, width is $2,5-4,0 \mathrm{~mm}$ [21].

C. frutex is a deciduous shrub, height is $1.5-3 \mathrm{~m}$; it forms a large amount of root growth, crown is rather densely branched; twigs are slender, glabrous; leaves are pinnate, due to the close proximity to each other look like palm; flowers are pea-like, bright golden-yellow, solitary, rarely collected on 2-3 pieces in the leaf axils. It blooms in May and June. Mature beans are bright brown, cylindrical, hard, glabrous, $3.5-4 \mathrm{~cm}$ in length, $4 \mathrm{~mm}$ in width. The fruit contains 1-4 seeds. The seeds are oblong or almost spherical, $4.2 \mathrm{~mm}$ in length and 2.5 $\mathrm{mm}$ in width and in thickness. Mass of 1000 seeds is $18-25 \mathrm{~g}$ [4]. The fruits ripen in midJuly. C. frutex blooms and bears fruit from 3 years of age [5].

Kuklina and Vinogradova (2013) found that in the Moscow region, the length of the fruit of $C$. frutex is $2.8-4.0 \mathrm{~cm}$, width is $0.3-0.5 \mathrm{~cm}$. Number of seeds in the fruit is $1-6$ pieces.

The materials of our research were mature fruits of $C$. arborescens and $C$. frutex, collected in the arboretum of the Tsytsin Main Botanical Garden of Russian Academy of Sciences (MBG RAS) in 2019.

Fresh fruits and seeds were measured using a caliper ShTs-II-250-0.05 (division price is $0.1 \mathrm{~mm}$ ), after drying at a temperature of $20-25^{\circ} \mathrm{C}$ to an air-dry state, they were weighed on a scale of the PocketScaleML-A03 brand. The repeatability of the tests is 50 times. The content of absolutely dry matter in the air-dry parts of the fruits was determined according to the standard method; raw materials were crushed using an electric grinder «ZMM»; dried in a drying cabinet «SHSU-M»[22]. The repeatability of the tests is 4-fold. Additionally, the number, fractions and mass fractions of mature and underdeveloped seeds in the fruit were determined, individually and collectively.

All quantitative data were processed by methods of variational statistics: the arithmetic mean, its error and deviation, the coefficient of variation, the accuracy indicator of the experiment were calculated. The comparison of the corresponding parameters for both species of Caragana was carried out by their arithmetic means, in accordance with the recommendations for small samples, according to the Student's criterion [23].

\section{Results and discussion}

Morphological features of mature fruits and seeds of $C$. arborescens and C. frutex are shown in fig. 1.

Mature fruits and seeds of both species have a similar external structure, slightly differing in color. The bean is cylindrical in shape; it is pointed at the ends; it is rounded 
across; it is opened at the dorsal and abdominal seams. The pericarp (skin, leaves of the fruit) is leathery, hard, dry. Its surface is bumpy, brown-brown heterogeneous color; the color of the inner surface of the leaf bordering the seeds, in $C$. arborescens is brown, in $C$. frutex is lighter, grey-brown (fig. 1, $A-C, F-H$ ). The seeds are attached by short ovules to the ventral seam of the fruit in a staggered order, forming a line that splits into two "thinned" rows with complete separation of the valves; along with mature seeds, there are underdeveloped ones (fig. 1, $C, H$ ).

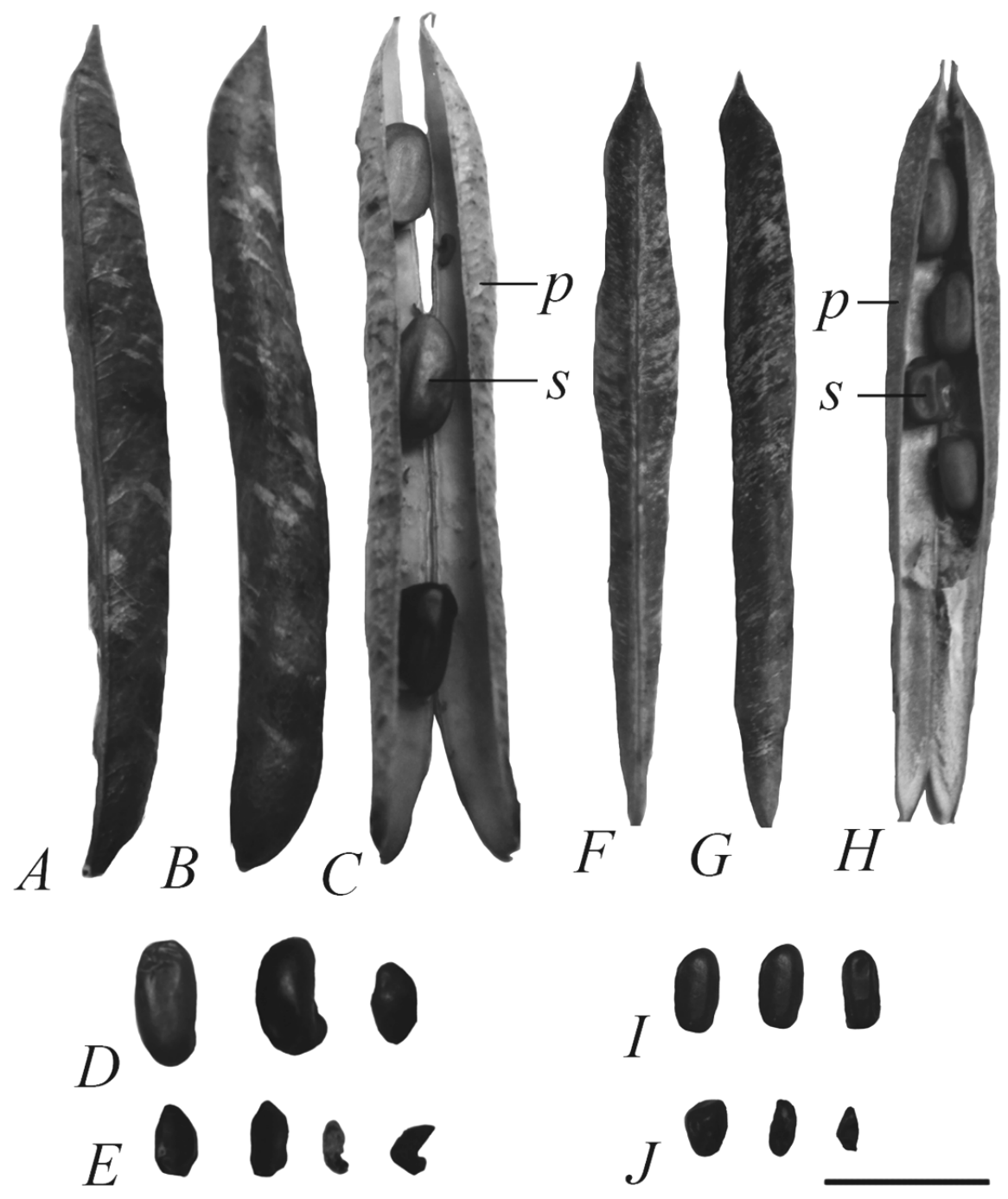

Fig. 1. Fruits and seeds of $C$. arborescens and $C$. frutex: $A$ - fruit $C$. arborescens on the front view, $B$ - fruit $C$. arborescens on the side view, $C$ - opened fruit of $C$. arborescens, $D$ - mature seeds of $C$. arborescens, $E$ - underdeveloped seeds of $C$. arborescens, $F$ - fruit $C$. frutex on the front view, $G-$ fruit $C$. frutex on the side view, $H$ - opened fruit of $C$. frutex, $I$ - mature seeds of $C$. frutex, $J-$ underdeveloped seeds of $C$. frutex; $p$ - pericarp, $s$ - seed. Scale bar $-1 \mathrm{~cm}$.

The diversity of seeds is manifested in their differences in shape, size and color. Normal seeds are cylindrical in shape, unfulfilled are angular, smaller. The color of seeds in $C$. arborescens varies from olive to black, in $C$. frutex is rather uniform, brown (fig. 1, $C$ - E, $H$ - 
$J)$. Elucidation of the nature and regularities of size and color heterospermia is an important fundamental and practical task [24].

The results of the study of the morphometric and weight characteristics of fruits and seeds of $C$. arborescens and $C$. frutex are presented in tables 1, 2.

Table 1. Morphometric characteristics of fruits and seeds of $C$. arborescens and C. Frutex $\left(\mathrm{t}_{\mathrm{tabl}}=\right.$ $1,98$, with $\mathrm{p} \leq 0,05)$

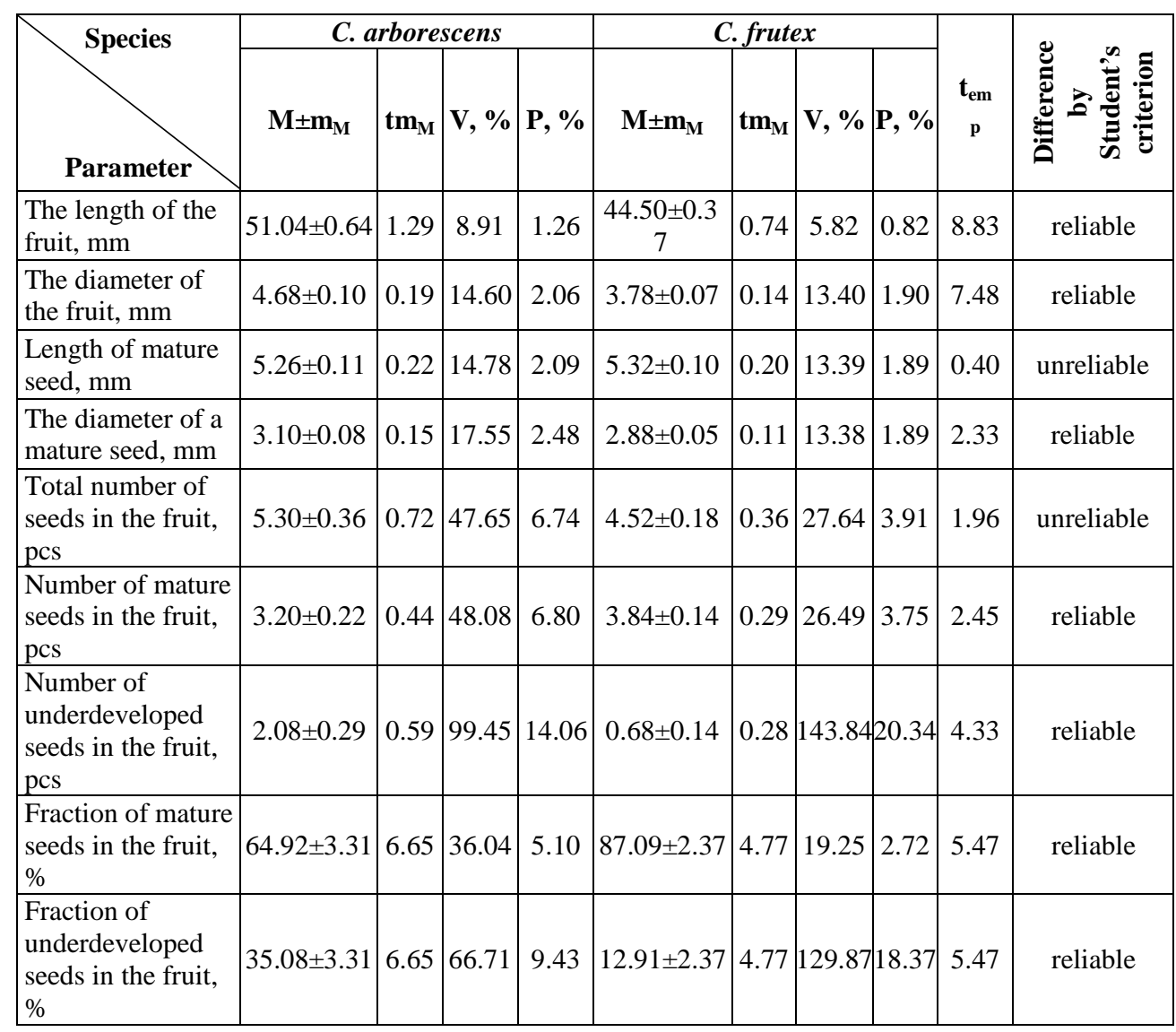

Note: $\mathrm{M} \pm \mathrm{m}_{\mathrm{M}}$ is arithmetic mean and its error, $\mathrm{tm}_{\mathrm{M}}$ is confidence interval, $\mathrm{V}$ is coefficient of variation, $\mathrm{P}$ is the accuracy rate of experience for the standard confidence level of $95 \%$ (precision experience is considered satisfactory if the metric values are not exceeding $5 \%$ ).

According to table 1, the fruit sizes of $C$. arborescens and $C$. frutex are $51.04 \pm 0.64 \mathrm{~mm}$ $\times 4.68 \pm 0.10 \mathrm{~mm}$ and $44.50 \pm 0.37 \mathrm{~mm} \times 3.78 \pm 0.07 \mathrm{~mm}$, respectively. According to the Student's criterion, $C$. arborescens beans are reliably superior to $C$. frutex beans in both length and diameter, because $t_{\text {emp }} \geq \mathrm{t}_{\mathrm{tabl}}: 8.83 \geq 1.98$ and $7.48 \geq 1.98$, respectively. Mature seeds of both species are approximately the same in length: $5.26 \pm 0.11 \mathrm{~mm}$ vs. $5.32 \pm 0.10$ $\mathrm{mm}(0.40 \leq 1.98)$, but differ in diameters: in C. arborescens they are reliably thicker than in C. frutex: $3.10 \pm 0.08 \mathrm{~mm}$ vs. $2.88 \pm 0.05 \mathrm{~mm}(2.33 \geq 1.98)$. The size characteristics of fruits and seeds of $C$. arborescens and $C$. frutex differ in average variation $(10 \% \leq \mathrm{V} \leq 20 \%)$, only the fruit lengths are slightly variable $(\mathrm{V} \leq 10 \%)$. The dimensions of all fruits and seeds are determined accurately $(\mathrm{P} \leq 5 \%)$. The length and width of the fruits, the width of the seeds of C. arborescens correspond to the literature data; as the data of classical scientific works on woody plants [4], and information about the variation in the size of fruits and seeds 
depending on the growing conditions of plants [21]. The length of the seed of $C$. arborescens, according to our data, exceeds that indicated in the classical literary source [4] and rather corresponds to the data of collections in the growing conditions in the Tomsk region and in Eastern Kazakhstan [21]. The length of the fruits of $C$. frutex exceeds both the data of the classical literature [4], and the study of colleagues in 2013, for the Moscow region [21]. The width of the fruits corresponds to the literature data [4, 21]. Seed sizes exceed those specified in the literature [4].

Table 2. Weight characteristics of fruits and seeds $C$. arborescens and C. Frutex $\left(\mathrm{t}_{\mathrm{tabl}}=1,98\right.$, with $\mathrm{p} \leq 0,05)$

\begin{tabular}{|c|c|c|c|c|c|c|c|c|c|c|}
\hline \multirow[t]{2}{*}{ ecies } & \multicolumn{4}{|c|}{ C. arborescens } & \multicolumn{4}{|c|}{ C. frutex } & \multirow{2}{*}{$t_{\text {emp }}$} & \multirow{2}{*}{ 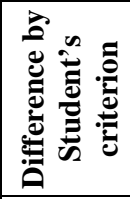 } \\
\hline & $\mathbf{M} \pm \mathbf{m}_{M}$ & $\mathbf{t m}_{\mathrm{M}}$ & $\mathrm{V}, \%$ & $\mathbf{P}, \%$ & $\mathbf{M} \pm \mathbf{m}_{\mathbf{M}}$ & $\operatorname{tm}_{M}$ & $\mathrm{~V}, \%$ & $\mathbf{P}, \%$ & & \\
\hline Fruit mass, $\mathrm{g}$ & $0.28 \pm 0.01$ & \begin{tabular}{|l|}
0.02 \\
\end{tabular} & 24.75 & 3.50 & $0.26 \pm 0.01$ & 0.02 & 21.01 & 2.97 & 2.14 & reliable \\
\hline $\begin{array}{l}\text { Mass of the } \\
\text { pericarp, } g\end{array}$ & $0.20 \pm 0.01$ & 0.02 & 26.80 & 3.79 & $0.16 \pm 0.01$ & 0.01 & 21.55 & 3.05 & 5.19 & reliable \\
\hline $\begin{array}{l}\text { Mass of seeds in } \\
\text { the fruit, } g\end{array}$ & $0.08 \pm 0.01$ & 0.01 & 43.88 & 6.21 & $0.10 \pm 0.01$ & 0.01 & 37.42 & 5.29 & 2.75 & reliable \\
\hline $\begin{array}{l}\text { Mass of mature } \\
\text { seeds in the } \\
\text { fruit, g }\end{array}$ & $0.07 \pm 0.01$ & 0.01 & 45.86 & 6,48 & $0.10 \pm 0.01$ & 0.01 & 38.49 & 5.44 & 3.27 & reliable \\
\hline $\begin{array}{l}\text { Mass of } \\
\text { underdeve-loped } \\
\text { seeds in the } \\
\text { fruit, g }\end{array}$ & $0.005 \pm 0.001$ & 0.002 & 159.65 & 22.58 & $0.002 \pm 0.001$ & 0.001 & 267.73 & 37.86 & 2.58 & reliable \\
\hline $\begin{array}{l}\text { Mass of mature } \\
\text { seed, g }\end{array}$ & $0.026 \pm 0.001$ & 0.003 & 40.69 & 5.75 & $0.027 \pm 0.001$ & 0.002 & 27.24 & 3.85 & 0.53 & unreliable \\
\hline $\begin{array}{l}\text { Mass of } \\
\text { underdeve-loped } \\
\text { seed, g }\end{array}$ & $0.003 \pm 0.001$ & 0.001 & 184.35 & 26.07 & $0.001 \pm 0.001$ & 0.001 & 288.56 & 40.81 & 2.12 & reliable \\
\hline $\begin{array}{l}\text { Mass fraction of } \\
\text { pericarp in the } \\
\text { fruit, } \%\end{array}$ & $71.30 \pm 1.31$ & 2,64 & 13,02 & 1.84 & $61.40 \pm 1.33$ & 2.67 & 15.28 & 2.16 & 5.30 & reliable \\
\hline $\begin{array}{l}\text { Mass fraction of } \\
\text { mature seeds in } \\
\text { the fruit, } \%\end{array}$ & $26.07 \pm 1.23$ & 2.47 & 33.38 & 4.72 & $37.87 \pm 1.35$ & 2.72 & 25.25 & 3.57 & 6.46 & reliable \\
\hline $\begin{array}{l}\text { Mass fraction of } \\
\text { underdeve-loped } \\
\text { seeds in the } \\
\text { fruit, \% }\end{array}$ & $2.03 \pm 0.47$ & 0.95 & 164.28 & 23.23 & $0.73 \pm 0.29$ & 0.58 & 281.26 & 39.78 & 2.35 & reliable \\
\hline
\end{tabular}

Note: $\mathrm{M} \pm \mathrm{m}_{\mathrm{M}}$ is arithmetic mean and its error, $\mathrm{tm}_{\mathrm{M}}$ is confidence interval, $\mathrm{V}$ is coefficient of variation, $\mathrm{P}$ is the accuracy rate of experience for the standard confidence level of $95 \%$ (precision experience is considered satisfactory if the metric values are not exceeding $5 \%$ ).

The fruits of $C$. arborescens and $C$. frutex contain approximately the same total number of seeds, $4-5$ pieces each: $5.30 \pm 0.36$ pieces and $4.52 \pm 0.18$ pieces, $1.96 \leq 1.98$; but the ratio of mature and underdeveloped seeds in them is different, approximately $3: 2$ and $7: 1$, respectively. The number and, especially, the fraction of mature seeds in $C$. arborescens is reliably lower than in $C$. frutex: $3.20 \pm 0.22$ pcs. vs. $3.84 \pm 0.14$ pcs. $(2.45 \geq 1.98)$ and $64.92 \pm 3.31 \%$ vs. $87,09 \pm 2,37 \%(5,47 \geq 1,98)$, respectively. The superiority of $C$. arborescens over $C$. frutex in the number and fraction of underdeveloped seeds is also reliable: 
$2.08 \pm 0.29$ pcs. vs. $0.68 \pm 0.14$ pcs. $(4.33 \geq 1.98)$ and $35.08 \pm 3.31 \%$ vs $12,91 \pm 2,37 \%$ $(5,47 \geq 1,98)$, respectively. In the fruits of both species, the total number of seeds and, separately, the number of mature and, especially, underdeveloped seeds varies greatly ( $V \geq 20 \%$ ); the accuracy of experiments exceeds $5 \%$, despite the representativeness of the samples. The number of seeds in the fruit of $C$. arborescens corresponds to the previously indicated in the literature, the number of seeds in the fruit of $C$. frutex exceeds the previously published data $[4,21]$.

Analysis of table 2 shows that fruits and their pericarps in $C$. arborescens are heavier than in $C$. frutex: $0.28 \pm 0.01 \mathrm{~g}$ vs. $0.26 \pm 0.01 \mathrm{~g}$ and $0.20 \pm 0.01 \mathrm{~g}$ vs. $0.16 \pm 0.01 \mathrm{~g}$, respectively. The ratio of pericarp and seeds in them is different. In the fruits of $C$. arborescens, compared with the fruits of $C$. frutex, the mass fraction is dominated by pericarps and underdeveloped seeds: $71.30 \pm 1.31 \%$ vs. $61.40 \pm 1.33 \%$ and $2.03 \pm 0.47 \%$ vs. $0.73 \pm 0.29 \%$, and mature seeds are on the contrary: $26.07 \pm 1.23 \%$ vs. $37.87 \pm 1.35 \%$, respectively, correlating with the quantitative characteristics of fruits and seeds (table 1). As well as mass fractions, the masses of mature seeds, as well as the total masses of seeds in the fruit, are smaller in C. arborescens than in $C$. frutex: $0.07 \pm 0.01 \mathrm{~g}$ vs. $0.10 \pm 0.01 \mathrm{~g}$ and $0.08 \pm 0.01 \mathrm{~g}$ vs. $0.10 \pm 0.01 \mathrm{~g}$, respectively. Underdeveloped seeds in $C$. arborescens are heavier than in $C$. frutex; both individually: $0.003 \pm 0.001 \mathrm{~g}$ vs. $0.001 \pm 0.001 \mathrm{~g}$, and collectively in the fruit: $0.005 \pm 0.001 \mathrm{~g}$ vs. $0.002 \pm 0.001 \mathrm{~g}$, respectively.

Almost all compared weight parameters of both species differ reliably. Only the masses of mature seeds are the same: $0.026 \pm 0.001 \mathrm{~g}$ and $0.027 \pm 0.001 \mathrm{~g}$, respectively $(0.53 \leq 1.98)$, despite the relatively larger size in $C$. arborescens (table 1). It is known that the constancy of the mass of mature seeds of some legumes allowed them to be used in ancient times as a weight measure. In $C$. arborescens and $C$. frutex, the weight parameters of fruits and their parts vary mainly strongly $(\mathrm{V} \geq 20 \%)$, only the mass fractions of pericarps are average $(10 \% \leq \mathrm{V} \leq 20 \%)$. The strong variation in the values of the arithmetic mean of the measurement data probably explains the excess of the accuracy indicators for them by more than $5 \%$. The mass of mature seeds in terms of 1000 pcs. in C. arborescens corresponds to the literature data and is closer to the lower limit, and in $C$. frutex it exceeds that indicated in the literature [4].

The water content of parts of the fruits of $C$. arborescens and $C$. frutex is characterized by data from table 3 .

Table 3. Content of absolutely dry matter in air-dry pericarps and seeds $C$. arborescens and C. frutex, \%

\begin{tabular}{|l|c|c|c|c|}
\hline \multicolumn{1}{|c|}{ Part of the fruit } & $\mathbf{M} \pm \mathbf{m}_{\mathbf{M}}$ & $\mathbf{t m}_{\mathbf{M}}$ & $\mathbf{V , \boldsymbol { \% }}$ & $\mathbf{P , \boldsymbol { \% }}$ \\
\hline Pericarp C. arborescens & $86.49 \pm 1.79$ & 5.68 & 4.13 & 2.07 \\
\hline Seeds C. arborescens & $84.91 \pm 1.31$ & 4.16 & 3,08 & 1.54 \\
\hline Pericarp C. frutex & $91.36 \pm 1.31$ & 4.15 & 2.86 & 1.43 \\
\hline Seeds C. frutex & $88.47 \pm 1.41$ & 4.49 & 3.19 & 1.59 \\
\hline
\end{tabular}

Note: $\mathrm{M} \pm \mathrm{m}_{\mathrm{M}}$ is arithmetic mean and its error, $\mathrm{tm}_{\mathrm{M}}$ is confidence interval, $\mathrm{V}$ is coefficient of variation, $\mathrm{P}$ is the accuracy rate of experience for the standard confidence level of $95 \%$ (precision experience is considered satisfactory if the metric values are not exceeding $5 \%$ ).

The fruits of $C$. arborescens, compared to $C$. frutex, are more hydrated, because their pericarps contain less dry matter: $86.49 \pm 1.79 \%$ vs. $91.36 \pm 1.31 \%$, as well as seeds: $84.91 \pm 1.31 \%$ vs. $88.47 \pm 1.41 \%$, respectively. In C. arborescens and C. frutex, according to the Student's criterion, the revealed differences in the content of absolutely dry matter in 
pericarps $-\mathrm{t}_{\mathrm{emp}}(2.20)<\mathrm{t}_{\mathrm{tabl}}(2.45)$ and in seeds $-\mathrm{t}_{\mathrm{emp}}(1.90)<\mathrm{t}_{\mathrm{tabl}}(2.45)$ are unreliable. The considered parameters differ in stability $(\mathrm{V} \leq 10 \%)$ and reliability $(\mathrm{P} \leq 5 \%)$.

The results of our analysis of the fruits of $C$. arborescens and $C$. frutex grown in the Moscow region in the arboretum of the MBG RAS, in general, do not contradict the literature data on these fruits growing in their natural habitats and in the conditions of introduction. However, there are discrepancies in some quantitative characteristics. In $C$. arborescens, a large variation in the number and mass of seeds in the fruit is noted in the literature: $5-8 \mathrm{pcs}$. and 0.025-0.044 g, respectively, without explanations regarding heterospermia. We found a smaller number of seeds in the fruit of $C$. arborescens compared to the literature: $4.9-5.7$ pcs., of which 3.0-3.4 pcs. are mature ones; the mass of the mature seed determined by us was $0.025-0.027 \mathrm{~g}$, i.e., within the lower limit of the interval indicated in the literature. The dimensions of the fruits studied by us correspond to the descriptions of other authors: $5.0-5.17 \mathrm{~cm} \times 4.6-4.8 \mathrm{~mm}$ vs. $3.5-6.5 \mathrm{~cm} \times 3.5-5.0 \mathrm{~mm}$, but the seeds were longer: $5.15-5.37 \mathrm{~mm} \times 3.02-3.18 \mathrm{~mm}$ vs. $4.5 \mathrm{~mm} \times 3.3 \mathrm{~mm}$, respectively, which is more consistent with the length of seeds in other conditions of introduction (the Tomsk region and Eastern Kazakhstan). According to the few data on the fruits of $C$. frutex, their length is less than that of the studied ones: $2.5-4 \mathrm{~cm}$ and $2.8-4.0$ $\mathrm{mm}$, against $4.4-4.5 \mathrm{~cm}$, and the number of seeds is less than in our experiment: $1-4$ pcs against 4-5 pcs, of which 4 pcs are mature ones.

Thus, the size and weight parameters for fruits and seeds, as well as the number of seeds of $C$. arborescens and $C$. frutex in the conditions of introduction in central Russia, were clarified. Plants of both species bear good fruit, the quantitative characteristics of their fruits and seeds sometimes exceed those indicated in the literature. According to the results of our research, the fruits of $C$. frutex are inferior to those of $C$. arborescens in size and mass, but presumably have the advantage of food use due to the superiority of their mature seeds in number, fruit fraction, mass, total mass and mass fraction in fruit.

\section{Conclusions}

The fruits of $C$. arborescens and $C$. frutex are the beans, similar in structure, having a typical morphological structure for representatives of the Fabaceae family, slightly different in color of the pericarp and seeds. Length and diameter of $C$. arborescens and $C$. frutex fruits are: $51.04 \pm 0.64 \mathrm{~mm} \times 4.68 \pm 0.10 \mathrm{~mm}$ vs. $44.50 \pm 0.37 \mathrm{~mm} \times 3.78 \pm 0.07 \mathrm{~mm}$, respectively; length and diameter of mature $C$. arborescens and $C$. frutex seeds are: $5.26 \pm 0.11 \mathrm{~mm} \times 3.10 \pm 0.08 \mathrm{~mm}$ vs. $5.32 \pm 0.10 \mathrm{~mm} \times 2.88 \pm 0.05 \mathrm{~mm}$, respectively. In the fruits of $C$. arborescens and $C$. frutex, the total number of seeds is: $5.30 \pm 0.36$ pcs vs. $4.52 \pm 0.18 \mathrm{pcs}$; the number and also fractions of mature seeds in the fruit are: $3.20 \pm 0.22 \mathrm{pcs}$ vs. $3.84 \pm 0.14$ pcs, and also $64.92 \pm 3.31 \%$ vs. $87.09 \pm 2.37 \%$; the number and also fractions of underdeveloped seeds in the fruit are: $2.08 \pm 0.29$ pcs. vs. $0.68 \pm 0.14$ pcs., and $35.08 \pm 3.31 \%$ vs. $12.91 \pm 2.37 \%$, respectively. In C. arborescens and C. frutex, the fruit mass is: $0.28 \pm 0.01 \mathrm{~g}$ vs. $0.26 \pm 0.01 \mathrm{~g}$; the pericarp mass and also its mass fraction in the fruit is: $0.20 \pm 0.01 \mathrm{~g}$ vs. $0.16 \pm 0.01 \mathrm{~g}$, and also $71.30 \pm 1.31 \%$ vs. $61.40 \pm 1.33 \%$; mass of the seeds in the fruit is: $0.08 \pm 0.01 \mathrm{~g}$ vs. $0.10 \pm 0.01 \mathrm{~g}$; mass of mature seed is: $0.026 \pm 0.001 \mathrm{~g}$ vs. $0.027 \pm 0.001 \mathrm{~g}$; the total mass of mature seeds, as well as their mass fraction in the fruit: $0.07 \pm 0.01 \mathrm{~g}$ vs. $0.10 \pm 0.01 \mathrm{~g}$; as well as $26.07 \pm 1.23 \%$ vs. $37.87 \pm 1.35 \%$; mass of underdeveloped seed: $0.003 \pm 0.001 \mathrm{~g}$ vs. $0.001 \pm 0.001 \mathrm{~g}$; the total mass of underdeveloped seeds, as well as their mass fraction in the fruit: $0.005 \pm 0.001 \mathrm{~g}$ vs. $0.002 \pm 0.001 \mathrm{~g}$; and $2.03 \pm 0.47 \%$ vs. $0.73 \pm 0.29 \%$, respectively. In $C$. arborescens and $C$. frutex, air-dry pericarps and seeds contain $86.49 \pm 1.79 \%$ vs. $91.36 \pm 1.31 \%$, and also $84.91 \pm 1.31 \%$ vs. $88.47 \pm 1.41 \%$ of absolutely dry matter, respectively. 


\section{References}

1. T. D. Nozdrina, E. V. Solomonova, N. A. Trusov, Environ Hum Ecol Stud 9, 2 (2019)

2. E. V. Solomonova, N. A. Trusov, T. D. Nozdrina, Adv Biol Sci Res 7 (2019)

3. E. V. Solomonova, N. A. Trusov, T. D. Nozdrina, T. P. Meer, V. N. Sorokopudov, C. Georgescu, Sci Stud Res Chem Chem Engin Biotech Food Ind 20, 4 (2019)

4. S. Ya. Sokolov, N. V. Shipchinskiy, Caragana - Caragana Lam., in Trees and shrubs of the USSR. Wild, cultivated and promising for introduction (USSR Academy of Sciences Publishing House, Moscow-Leningrad, 1958)

5. L. S. Plotnikova, M. S. Aleksandrova, Yu. E. Belyaeva, E. M. Nemova, N. V. Ryabova, E. I. Yakusheva, Woody plants of the Main Botanical Garden named after N. V. Tsitsin Russian Academy of Science: 60 years of introduction (Nauka, Moscow, 2005)

6. M. L. Zhang, P. W. Fritsch, B. C. Cruz, Mol Phylog Evol 50 (2009)

7. U. P. Hedrick, Sturtevant's Edible Plants of the World (Dover Publications, New York, 1972)

8. T. Tanaka, Tanaka's Cyclopaedia of Edible Plants of the World (Keigaku Publishing, Tokyo, 1976)

9. M. L. Reva, V. M. Lipovetskiy, Plants in everyday life (Donbass Publ., Donetsk, 1977)

10. G. Kunkel, Plants for Human Consumption (Koeltz Scientific Books, Koenigstein, 1984)

11. S. Facciola, Cornucopia - A Source Book of Edible Plants (Kampong Publ., Vista, 1990)

12. D. Frohne, J. Pfänder, A Colour Atlas of Poisonous Plants (Wolfe, London, 1984)

13. K. Fern, Plants for a Future. Caragana arborescens - Lam. [Online] Avaliable at: https://pfaf.org/user/plant.aspx?LatinName=Caragana+arborescens (Accessed 10.02.2021)

14. W. Bean, Trees and Shrubs Hardy in Great Britain (J. Murray, London, 1981)

15. E. Crane, Garden Plants Valuable to Bees (International Bee Research Association, London, 1981)

16. B. Davis, Climbers and Wall Shrubs (Viking, London, 1990)

17. R. Phillips, M. Rix, Shrubs (Pan Books, London, 1989)

18. S. F. Ponomarenko, Sem. Fabaceae, in Comparative anatomy of seeds (Peace and family Publ., Saint Petersburg, 1996)

19. A. R. Hasanshina, Botanical and pharmacognostic study of Siberian peashrub (Caragana arborescens Lam.) (Moscow, 2010)

20. V. V. Partilkhaev, L. M. Tankhaeva, D. N. Olennikov, Chem Plant Raw Mat 1 (2013)

21. A. G. Kuklina, Ju. K. Vinogradova, Bull Main Bot Gard 3 (2013)

22. A. I. Ermakov, V. V. Arasimovich, M. I. Smirnova-Ikonnikova, I. K. Murri, Biochemical research methods of plants (State Publishing House of Agricultural Literature, Moscow-Leningrad, 1952)

23. G. N. Zajcev, Mathematics in Experimental Botany (Nauka Publ., Moscow, 1990)

24. R. N. Telebokova, The place of heterospermia among other types of intrapopulation variability of seeds in four species of legumes of the tribe Fabaceae (Moscow, 2009) 